\title{
WELLCOME HISTORICAL MUSEUM AND LIBRARY
}

\begin{abstract}
$\mathrm{D}^{\mathrm{n}}$ R. F. N. L. POYNTER, formerly chief librarian of the Wellcome Historical Medical Library has been appointed a director to take charge of both the Wellcome Historical Modical Museum and the Historical Medical Library. His appointment is part of a general reorganiza. tion following the retirement of Dr. E. Ashworth Underwood as director of the Wellcome Historical Modical Museum.

Dr. F. N. L. Poynter joined the staff of the library as assistant librarian in 1930 when Sir Henry Wellcome was himself director of the Museum and Library. He became sub-librarian in 1938, deputy librarian in 1946 and chief librarian in 1954. He received his training as a medical historian from the late Prof. Max Neuburger. In addition to his other duties he is secretary-general of the International Academy of the History of Medicine and honorary secretary of the Faculty of the History of Medicine of the Society of Apothecaries. He is the author of a number of books and more than a hundred papers on the history of medicine.

The Wellcomo Historical Medical Museum and the Historical Medical Library are housed in the Wellcome Building in Euston Road, London. Both are basod on collections initiated by the late Sir Henry Wellcome, who diod in 1936. The Library contains approximately 250,000 printed books, pamphlots and journals, 10,000 manuscripts (of which half are in oriental languages) and 100,000 autograph letters of modical and scientific interest. The Museum contains what is probably the most comprehensive collection yet made of scientific instruments and antiquities of intorest for tho History of Medicine.
\end{abstract}

As part of the reorganization also, Dr. Edwin Clarke has been appointed medical historian to the Musoum and Library and Mr. J. W. Barber-Lomax is to be administrative officer and veterinary historian. Dr. Clarke was formorly associate professor of the history of medicine in Yale University. Mr. Barber-Lomax, who is ono of the leading veterinary historians in Great Britain, was formerly manager of the Professional Services Department, Veterinary Division of the Wellcome Foundation, Ltd.

Mr. E. Gaskell, formerly sub-librarian, has been elected librarian of the Historical Medical Library and Mr. E. Freeman sub-librarian.

Dr. Ashworth Underwood retired from the Wellcome Historical Modical Museum this year after nearly oighteen years as its director. Despite the frustrations of space restriction, resulting primarily from the War, Dr. Ashworth Underwood was able to koop a representative exhibition open for the public and was always striving for the proper deployment of the collection so that full use could be mado of it. Important exhibitions of topical subjects were regularly arranged by him during his torm of office and his great knowledge of the subject onabled him to give much help to many students of the history of medicine.

Before his appointment as director of the Historical Medical Museum Dr. Ashworth Underwood had boon medical officer of health for West Ham and an honorary lecturer in the Department of the History of Science and Philosophy in Univorsity College, London. $\mathrm{He}$ has published many papers and books, among them the sccond edition of Singer's Short History of Medicine.

\section{BALTHAZAR VAN DER POL GOLD MEDAL FOR SCIENTIFIC RADIO}

$\mathrm{D}^{2}$ URING the general assembly of the International Scientific Radio Union (URSI) in Tokyo, September 1963 , an evening was devoted to honouring the memory of the late Dr. Balth. van der Pol (1889-1959), who had devoted an important part of his numerous activities to the growth of URSI, in which he was so keenly interested. The occasion was the first presentation of the Gold Medal founded by the generosity of Mrs. van der Pol in memory of her late husband. In consultation with the Board of Officers of URSI, it was decided that the Medal was to be awarded to an outstanding radio scientist who, during the throe-year period preceding the year of each general assembly, has made a valuable contribution in one of the fields of activity of the Union either by his research work, discoveries or achievements, or by any other activity.

In a volume recently published (June 1964) under the title Van der Pol Memorial Lecture 1963, by the Secretary. General of URSI (7 Place Emile Danco, Bruxelles, Belgium), the proceedings at ${ }^{\circ}$ this special meeting are recorded in full. After a short opening address by the president, Dr. R. L. Smith-Rose, a review of the life and scientific work of Balthazar van dor Pol was given by Prof. Ch. Manneback, treasurer of URST.

He recalled that, after graduating at the University of Utrecht in 1916, van der Pol went to England, where he worked with Prof. (Sir Ambrose) Fleming in the University of London, and with Prof. (Sir J. J.) Thomson in the Cavendish Laboratory, Cambridge. He returned to the Notherlands in 1919, and, after obtaining his doctor's degree at Utrecht, ho joined the research laboratories of the Philips Company at Eindhoven in 1922. He remained there until 1949, when he was appointed the first director of the International Radio Consultative Committee (CCIR) in Geneva. After his retirement in 1956, he was visiting professor in the University of California, Berkeley, and, in 1958, in Cormell University, Ithaca.

Following this exposition at the ceremony in Tokyo, the first van der Pol Gold Medal was then presented to Prof. Martin Ryle by Mrs. van der Pol in recognition of his leadership of the radio astronomy group at the Mullard Observatory of the Cavendish Laboratory, Cambridge. Remarking on the appropriateness of the award, Mrs. van der Pol recalled the period in 1917 during which her late husband had worked at the Cavendish Laboratory, where he formed a life-long friendship with Dr. (Sir Edward) Appleton and other British scientists. The new group under Prof. Ryle has made outstanding contributions to astronomy, problems of cosmology, and to scientific radio. In particular, the Cambridge scientists have developed new aerial systems, especially suited to radio astronomical research. Following his acceptance of the Medal, Prof. Rylo gave a lecture on "Giant Radio Telescopes", which is reproduced with diagrams and photographs in the volume just published. In the course of his lecture, Prof. Ryle outlined the two main problems of radio astronomy: the limited resolving power obtainable compared with optical astronomy; and the extreme weakness of the signals to be received. A brief description was given of the design and performance of the three telescopes operating on the principle of 'aperture synthesis', which was developed at Cambridge. Some details were also given of a fourth and considerably more powerful instrument under construction.

After the president had thanked Prof. Ryle for his lecture, Mrs. van der Pol presented a second Gold Medal 